\title{
What Determines Innovativeness of Micro and Small Enterprises (MSEs) in Ethiopia? Evidence from Debre Berhan Town, Ethiopia
}

\author{
Abebe Getaneh Kebede \\ Lecturer, Department of Management, College of Business and Economics, \\ Debre Berhan University, Ethiopia
}

\begin{abstract}
Innovation is considered to be the driving force of competitiveness and growth of firms as well as countries. However, most of MSEs in Ethiopia particularly in Debre Berhan town they were not innovative. Thus, the aim of this article was to identify determinants of innovativeness of MSEs in Debre Berhan town. Data were obtained using questionnaires primarily. The sample consists of 326 MSEs, but the response rate was 90.18\%. Both stratified and simple random sampling techniques were employed in the study. Both descriptive statistics and econometric analysis were employed. From descriptive statistics percentage and frequency and chi-square test and from econometric analysis, binary logistics analysis was used. The binary logistics results confirmed that competition in the market $(\mathrm{OR}=0.035, \mathrm{P}<.01)$ and engagement in research $(\mathrm{OR}=0.126, \mathrm{P}<.001)$, access to finance $(\mathrm{OR}=0.190, \mathrm{P}<.005)$ respectively found to be major factors of innovation. However, vocational training and consultancy service did not have statistically significant influence on innovation behaviour. Based on the findings of the study, possible solutions were recommended to the concerned government bodies to enhance innovativeness of MSEs in the study area.
\end{abstract}

DOI: $10.7176 /$ RHSS/11-19-03

Publication date:October $31^{\text {st }} 2021$

\section{Introduction}

Nowadays sources of competitive advantage and economic development are sought in the sphere of innovation (Zastempowski \& Przybylska, 2016). Innovation is considered to be the driving force of competitiveness and growth of firms as well as countries(Talegeta, 2014). Moreover, they have been incorporated into governmental and international strategic development programmes(Zastempowski \& Przybylska, 2016). An innovation in a small enterprise in the developing countries context is largely an adoption of a product, process, or method that have already been adopted elsewhere but new to the firm and not necessarily new to the world, region, country, or industry (Gebreeyesus, 2014)

Enterprises create job opportunities and income for the youth and poor in a developing country. Innovation is important for enterprises to become and remain competitive, to move to higher return activities, and to grow, hence creating new employment and income. With increasing competition and quickly spreading of knowledge, the future of many businesses depend upon their ability to innovation (Talegeta, 2014). However, despite these benefits of innovation, not all firms undertake innovation projects (Cisková \& Durčeková, 2019).

The key to the success of companies and entire economies in the world today is innovation( Talegeta, 2014;Božić \& Rajh, 2016 and Havierniková \& Kordoš, 2019). Current research, theory development and policy formulation to promote innovation have mainly focused on innovation in the more advanced economies, whilst investigation of these issues in low income countries to date has been limited(Voeten, Jaap; Gizaw \& Publication, 2018). However, the report of Debre Berhan Technic and Enterprise Development Office (2020/21) and environmental scan evidence shows that low innovativeness of small and Medium Enterprises (SMEs) in Debre Berhan.

Firms' innovativeness can be explained by studying factors that enhance innovation performance but also by studying factors that impede it(Božić \& Rajh, 2016;Abdu, M., \& Jibir, 2018). Empirical studies on determinants of innovation by small firms in Africa are relatively scarce (Adebowale, B. A., Diyamett, B., Lema, R., \& Oyelaran-Oyeyinka, 2014 and Abdu, M., \& Jibir, 2018).This is also true in Ethiopia as well. Thus, this study aimed at examining the determinants of innovation practice of MSEs in the Debre Berhan town, Ethiopia. Regarding its contribution, the author expect that the paper may bring an awareness of managers and owners of micro and small companies for the need to foster innovative practices that can help increase the competitiveness and survival of this type of organization. The paper is structured as follows: The next section provides the literature reviewed on determinants of innovation of MSEs; the third and fourth section presents the methods and conclusion and recommendation sections consecutively. At the end the future research directions are presented.

\section{Literature Review}

Innovation the implementation of a new or significantly improved product (good or service), or a process, or a 
new marketing method, or a new organizational method in business practices, in the organization of the workplace or in external relationships $(\mathrm{OECD}, 2005)$. Innovation has been mostly related to new technologies and/or new knowledge, which must be different from everything else created so far(Kotey, B., \& Sorensen, 2014).

The role of innovation as a crucial driving force of economic development is widely acknowledged in particular within the business setting(Talegeta, 2014). Innovations and innovation policies and strategies implementations are one of the most important aspects of current regional economics and business development issues(Havierniková \& Kordoš, 2019).

Access to finance is one of the determining factor of firm's innovativeness(Szczepanska-Woszczyna (2014); Talegeta (2014), Njiraini et al.(2018) and Zajkowska(2015). In addition to this, among the human capital variables vocational training is found to have a strong effect on the innovation activity (Szczepanska-Woszczyna, 2014 and Abderrezzak et al., 2016).

Engagement in research and development significantly determine enterprise innovation(Abderrezzak et al., 2016 and Talegeta,2014).Furthermore, Competition in product market among firms in the same industry has high influence on the enterprises' innovation practice(Bos, J. W., Kolari, J. W., \& van Lamoen, 2013 and Voeten, Jaap; Gizaw \& Publication,2018).

\section{Gap of Literatures}

A firm's location also affects many other external and internal factors that influence innovation(Kruger, 1991 and OECD, 2018).In the investigations of (Mancusi, M. L., \& Vezzulli, 2010) and Zeleny( 2012) it was found that consulting is of paramount importance for firms' innovativeness. However, as discussed earlier the studies conducted on innovativeness of MSEs did not incorporate the influence of these two factors make their studies more comprehensive. Thus, this study tried to examine their influence with the other factors determining MSEs to innovation practice in the study area.

\section{Materials and Methods}

\section{Research Methodology}

\subsection{Study Area Profile}

Debre Berhan is a town in central part of Ethiopia which is located in the North Shewa Zone in the Amhara Region, about 130 kilometres northeast of Addis Ababa, the capital city of Ethiopia. The town has a latitude and longitude of $9^{\circ} 41^{\prime} \mathrm{N} 39^{\circ} 32^{\prime} \mathrm{E}$ and an elevation of 2,840 meters. The town has nine Kebeles, the lowest administration in Ethiopia, with a total population of 103,450 whom 46, 553 are men and 56,897 women.
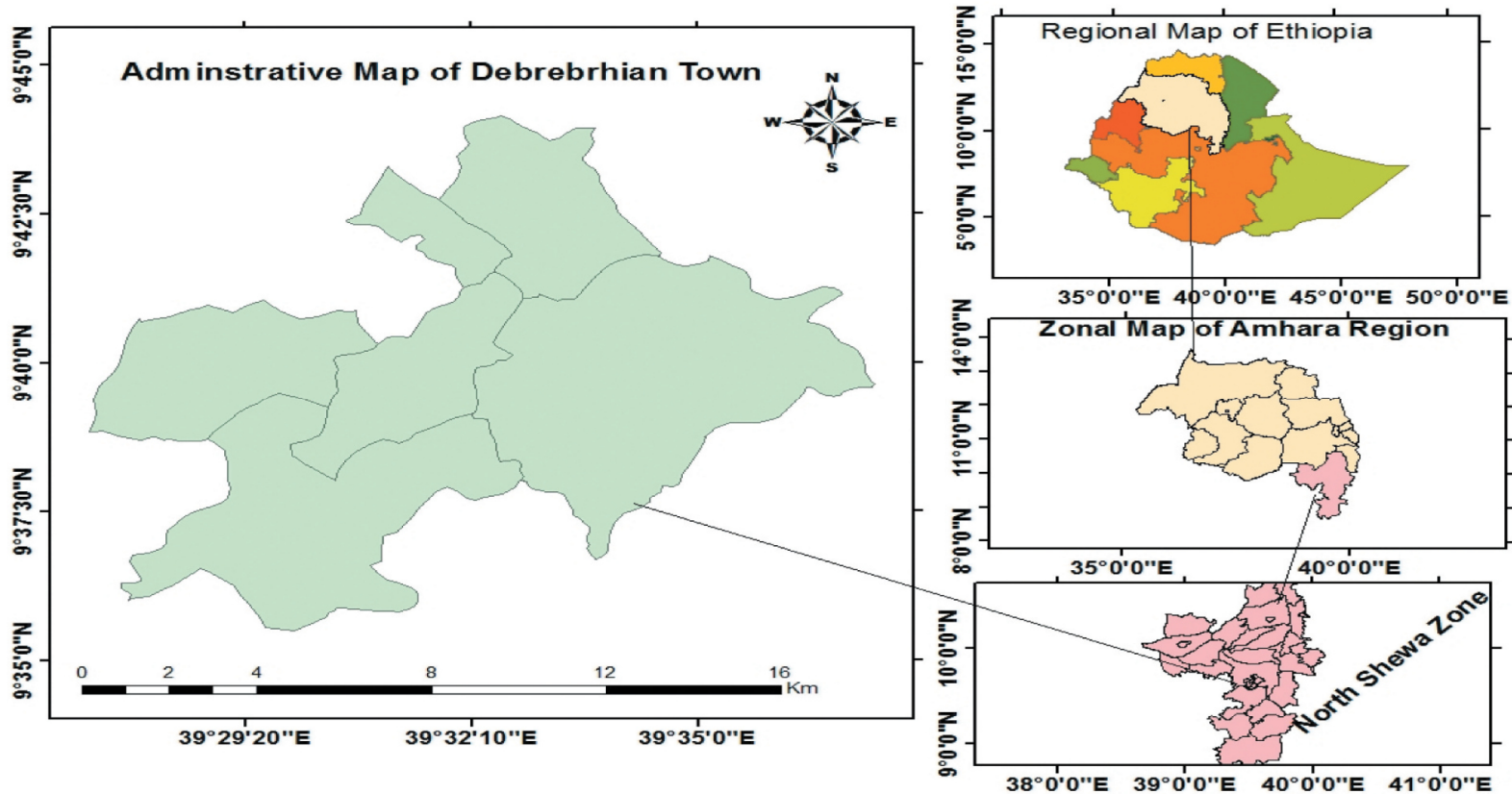

\subsection{Research Approach}

The study used this approach because the study aimed at identifying significant determinants of Micro and Small Enterprises' innovation practice in the study area.

\subsection{Sampling Method and Size}

The 2020/21 report of Debre Berhan TVET and Enterprise Development Office, there were 1741 registered Micro and Small Enterprises in five different sectors in the town. Stratified sampling technique was employed to take 
sample MSEs from each sector. Then simple random sampling technique was used in order to take MSEs from each stratum proportionally. This study applied a simplified formula provided by Yamane (1967) to determine the required sample size at $95 \%$ confidence level and 5\% the margin of error. Yamane formula is expressed as;

$\mathrm{n}=\mathrm{N} /\left(1+\left(\mathrm{N}^{*} \mathrm{e}^{2}\right)\right.$

$\mathrm{n}=1741 /(1+1741 * 0.0025)$

$\mathrm{n}=326$

Where: $\mathrm{n}=$ sample size; $\mathrm{N}=$ the total number of registered MSEs and $\varepsilon=$ error tolerance. Sample respondent distribution from each sector is depicted as follows;

\begin{tabular}{|lll|}
\hline Name of the Sector & \multicolumn{2}{c|}{ Table 3.1.Sampling Distributions } \\
\hline Manufacturing & No of MSEs & No Sampled of MSEs \\
\hline Construction & 176 & 33 \\
\hline Service & 179 & 34 \\
\hline Urban Agriculture & 497 & 93 \\
\hline Trade & 39 & 7 \\
\hline Total & 850 & 159 \\
\hline
\end{tabular}

\subsection{Data Collection Methods}

Both primary and secondary sources of data were used in this study. From primary data questionnaires were used. Testing of the questionnaire was done in the actual study area in order to cross check the relevance of its contents. Furthermore, secondary data were collected by reviewing of the available research papers and government reports in order to identify the existing knowledge gap needed to be filled through research.

\subsection{Description of the Model of Variable and Its Measurement}

\begin{tabular}{|c|c|c|c|c|c|}
\hline Variable & $\begin{array}{l}\text { Variable } \\
\text { Label }\end{array}$ & Description & $\begin{array}{l}\text { Types of } \\
\text { variables }\end{array}$ & Measurement variables & $\begin{array}{l}\text { Expected } \\
\text { sign }\end{array}$ \\
\hline $\begin{array}{l}\text { Dependent } \\
\text { variable }\end{array}$ & INNOV & Innovativeness & Dummy & $\begin{array}{l}1=\text { Not } \\
\text { innovative }, 2=\text { Innovative }\end{array}$ & \\
\hline \multirow{6}{*}{$\begin{array}{l}\text { Independent } \\
\text { variables }\end{array}$} & ACFN & Access to finance & Dummy & $1=\mathrm{No}, 2=\mathrm{Yes}$ & + \\
\hline & VOTR & $\begin{array}{l}\text { Got } \quad \text { vocational } \\
\text { training }\end{array}$ & Dummy & $1=$ No, $2=$ Yes & + \\
\hline & COSER & $\begin{array}{l}\text { Obtain consultancy } \\
\text { service }\end{array}$ & Dummy & $1=$ No, $2=$ Yes & + \\
\hline & BULOC & $\begin{array}{l}\text { Business location } \\
\text { from } \\
\text { suppliers/customers }\end{array}$ & Dummy & $1=$ Far, $2=$ Near & + \\
\hline & COMP & $\begin{array}{l}\text { Competition in the } \\
\text { market }\end{array}$ & Dummy & $1=$ No, $2=$ Yes & + \\
\hline & ERD & $\begin{array}{lr}\text { Engagement } & \text { in } \\
\text { research } & \text { and } \\
\text { development } & \end{array}$ & Dummy & $1=$ No, $2=$ Yes & + \\
\hline
\end{tabular}

\subsection{Methods of Data Analyses}

Once the data collected, they were edited, coded and entered into computer Software program for social sciences (SPSS) version 25.Descriptive statistics such as frequency and percentage; from inferential statistics chi-square test and binary logistics analysis were used so as to examine the major factors influencing MSE's innovativeness.

\subsection{Model Specification}

The binary logistic regression model characterizing innovativeness or not by the sample MSEs was used as follows:Pi $=\frac{e^{Z i}}{1+e^{Z i}}$ Where $\mathrm{Pi}$ is the probability of having innovative practice for the $\mathrm{i}^{\text {th }} \mathrm{MSE}$ and $\mathrm{Zi}$ is a set of factors affecting innovative practice of MSEs $(\mathrm{Xi})$ and the disturbance term $\left(\mathrm{U}_{\mathrm{i}}\right)$ expressed as: $\mathrm{Zi}=\beta o+$ $\sum_{i=1}^{n} \beta \mathrm{iXi}+\mathrm{Ui}$, Where $\beta 0$ is the intercept, $\beta \mathrm{i}$ are the slope parameters in the model and $\mathrm{n}$ is the number of explanatory variables.

\section{Results and Discussion}

\subsection{Descriptive results on Profile of Respondents}

For questionnaire survey, 326 owners of Micro and small enterprises were selected and questionnaires were 
distributed owners of each MSEs, but $90.18 \%$ of them response rate was used. $38.8 \%$ were male and the remaining were females.

\subsubsection{Result on Innovation practice of MSEs}

\begin{tabular}{|c|c|c|}
\hline \multicolumn{3}{|c|}{ Table 4.1.MSEs Innovation practice } \\
\hline \multirow{4}{*}{$\begin{array}{l}\text { Did you make } \quad \text { an important } \\
\text { improvement/change to your product/service } \\
\text { recently? }\end{array}$} & Response & Frequency $(\%)$ \\
\hline & No & $179(60.9)$ \\
\hline & Yes & $115(39.1)$ \\
\hline & Total & 294(100) \\
\hline
\end{tabular}

As shown in the Table 4.1., about $39.1 \%$ of the enterprises said yes for the question "Did you make an important improvement/change to your product/service recently?" and the remaining responded no. This implies most of the MSEs did not practice innovation practice. This finding is in line with the result of the study of Cisková \& Ďurčeková(2019).

Those, who responded yes, were then asked to disclose what type of improvement was involved. The type of innovation activities they were being engaged were summarized in three types: product innovation $(88.3 \%$ of enterprises) such as providing new/quality/better design or an increasing variety of products (61\% of enterprises), process innovation-machinery investment, improving or increasing business premises, furniture, and equipment, organizational and skill improvement (56.6\% of enterprises)-improving the skill of workers and marketing innovation( $77.9 \%$ of enterprises ) -managers and more advertisement, shorter delivery time. This implies among those practicing innovation activities, most of them were engaged in product innovation.

\subsubsection{Chi-square Test Result}

\begin{tabular}{|lllll|}
\hline Variable & \multicolumn{2}{l}{ Table 4.2.Chi-square Result } & Cramer's V \\
\hline Business location & Chi-square & P-value & df & Cram \\
\hline Consultancy service & 113.586 & $0.000^{* *}$ & 1 & 0.622 \\
\hline Engagement in research & 0.385 & 0.551 & 1 & 0.036 \\
\hline Vocational training & 152.018 & $0.000^{* *}$ & 1 & 0.719 \\
\hline Competition in the market & 9.145 & $0.002^{*}$ & 1 & 0.176 \\
\hline Access to finance & 178.091 & $0.000^{* *}$ & 1 & 0.778 \\
\hline
\end{tabular}

NB:* refers significant at $5 \%$ and $* *$ refers to significant at $1 \%$

As shown in table 4.2.above, business location with $\mathrm{X}^{2}=113.586, \mathrm{P}<.001$; engagement in research with $\mathrm{X}^{2}=152.018, \mathrm{P}<.001$; vocational training with $\mathrm{X}^{2}=9.145, \mathrm{P}<0.005$; competition in the market with $\mathrm{X}^{2}=178.091$, $\mathrm{P}<.001$ and access to finance with $\mathrm{X}^{2}=9.145, \mathrm{P}<0.005$ were found statistically significant associations with innovation practice of MSEs in the study area. However, consultancy service was found no statistically significant association with innovativeness of MSEs in the study area.

\subsection{Econometric Model Results}

\subsubsection{Diagnostics Test Results}

In the econometric analysis, the study applies binary logistics regression For the purpose of effective development of the model the required diagnostics tests such as likelihood test (Model summary) and Hosmer and Lemeshow test were tested as shown below.

\begin{tabular}{l} 
Step \\
$\begin{array}{l}-2 \text { Log likelihood } \\
116.773^{\mathrm{a}}\end{array}$ \\
$\begin{array}{l}\text { Cox \& Snell R Square } \\
\text { a. Estimation terminated at iteration number } 7 \text { because parameter estimates changed by less than } .001 .\end{array}$ \\
\hline \multicolumn{2}{l}{ In this section the model summary is discussed, in order to identify factors influencing innovation practice of } \\
MSEs, binary logistic regression model was used. Moreover, the joint impact of all predictor variables on the \\
dependent variables also determine by using the concept of Nagelkerke $\mathrm{R}^{2}$ which is $82.7 \%$. In the table, the -2 Log \\
Likelihood statistics is 116.773 . The result of Cox and Snell $\mathrm{R}^{2}$ indicates that $61.0 \%$ of the variation in the \\
dependent variable is explained by the predictors. This is assumed to be good enough.
\end{tabular}

\begin{tabular}{cccc}
\hline & \multicolumn{3}{c}{ Table 4.4.Hosmer and Lemeshow Test } \\
Step & Chi-square & df & Sig. \\
1 & 8.152 & 7 & .319 \\
\hline
\end{tabular}

As it is observed from the table above since P-value is 0.319 is greater than the level of significance at $5 \%$. We can conclude that the data fits the model well. Since the p-value is 0.319 which is insignificant therefore our fitted logistic regression model is good fit. 


\subsubsection{Binary Logistics Results}

\begin{tabular}{|c|c|c|c|c|c|c|c|}
\hline & & 5. Bin & gistic & esults & & & \\
\hline & & B & S.E. & Wald & $\mathrm{df}$ & P-value & Odds \\
\hline & & & & & & & Ratio \\
\hline Step & Business location & 2.069 & .539 & 14.753 & 1 & $.000 * *$ & .126 \\
\hline $1^{\mathrm{a}}$ & Consultancy service & .596 & .517 & 1.328 & 1 & .249 & 1.815 \\
\hline & Engagement in research & 1.885 & .595 & 10.055 & 1 & $.002 *$ & .152 \\
\hline & Vocational training & .149 & .498 & .090 & 1 & .764 & .861 \\
\hline & Competition in market & 3.353 & .530 & 40.021 & 1 & $.000 * *$ & .035 \\
\hline & Access to finance & 1.662 & .560 & 8.811 & 1 & $.003 *$ & .190 \\
\hline & Constant & 4.187 & .696 & 36.202 & 1 & .000 & 65.824 \\
\hline
\end{tabular}

NB:* refers significant at $5 \%$ and $* *$ refers to significant at $1 \%$

As it is clearly seen from the table 4.5 above, access to finance was significantly affecting innovation practice of MSEs with $\mathrm{OR}=1.662, \mathrm{P}<0.05$. The estimated odd ratio of MSEs which were established near to the supplier/customer was 0.190 ..This implies that the probability of MSEs were in competitive industry is 0.190 times more likely be innovative controlling for the other covariates in the model. This may be..... This result is consistent with the findings of the studies of Szczepanska-Woszczyna (2014); Talegeta (2014), Zajkowska(2015) and Njiraini et al.(2018)

Business location is positively and significantly affecting innovative practice of MSEs the $1 \%$ level of significance as it can be noted in the table 4.5 above. The estimated odd ratio of MSEs which were established near to the supplier/customer was 0.126 ..This implies that the probability of MSEs which were located near to their suppliers/customers is 0.011 times more likely be innovative controlling for the other covariates in the model. This result is consistent with the studies of Kruger(1991), Mancusi, M. L., \& Vezzulli(2010) and OECD(2018).

Similarly, engagement in research was positively and significantly innovative behaviour of MSEs the $5 \%$ level of significance. The estimated odd ratio of MSEs which were engaged in research was 0.861.This implies that the probability of MSEs which were engaged in research is 0.0861 times more likely be innovative controlling for the other covariates in the model. This result is in line with Szczepanska-Woszczyna (2014); Talegeta (2014) and Zajkowska(2015) and Njiraini et al.(2018).

Table 4.5.also depicted that competition in the market is positively and significantly affecting innovative practice of MSEs the 1\% level of significance. The estimated odd ratio of MSEs which were established near to the supplier/customer was 0.035 ..This implies that the probability of MSEs were in competitive industry is 0.035 times more likely be innovative controlling for the other covariates in the model. This result is consistent with the findings of the studies of Bos, J. W., Kolari, J. W., \& van Lamoen (2013 and Voeten, Jaap; Gizaw \& Publication (2018).

Consultancy service was found statistically insignificant contribution to innovative behaviour of MSEs at 5\% in the study area. Thus, the result may be due to this reason, but the result of the study of Mancusi, M. L., \& Vezzulli (2010) and (Zeleny, 2012) contradicts with this finding which concluded that consulting is of paramount importance for firms' innovativeness. Similarly, from the results of the study it was possible to conclude that vocational training's contribution to the innovativeness of MSEs was insignificant. This result is contradicts with the result of Szczepanska-Woszczyna, 2014 and Abderrezzak et al., 2016). Those MSEs which get vocational training and/or consultancy service may not enable MSEs to be innovative unless they internalize and apply the training and/or advice they obtained.

\section{Conclusions and Recommendations}

The results of this exploratory study provide an insight into problems that impact innovation activities and lead to low innovation performance in SMEs in Debre Berhan town. Both stratified and simple random sampling techniques to select 294 sample MSEs. Data were collected through structured questionnaires. From descriptive statistics results, majority of MSEs were not innovative.

The results of binary logistic regression was employed in the study and it was found that access to finance, business location, engagement in research and development and competition in the market were found major factors contributing to the innovative behaviour of MSEs. However, the other variables vocational training and consultancy service had no statistically significant influence with business linkage.

The researcher recommended that the concerned government bodies ought to give emphasis on enabling and supporting MSEs in the way they actively engage in research and use the information collected in their business operation. Besides, owners of MSEs should be well informed about the significance of being located near to suppliers (for manufacturing enterprises) and near to customers for non-manufacturing enterprises)extending business development service such as consultancy service and trainings to all MSEs and facilitating the ease ways of accessing credit to MSEs in the study area. This may be done by reducing the bureaucracy and so on. Furthermore, the government had better encourage competition in the product market space to MSEs in the study. 


\section{Future Research Direction}

The researcher recommended that further study with additional predictor variables such as firm characteristics (such as firm size and age) and entrepreneur attributes (such as level of education and personality of the owner).Furthermore, the study was delimited to one city, Thus, it was better to conduct the study in wider geographic area in order to make the results more informative policy inputs.

\section{References}

Abderrezzak, B., Wafaa, B., \& Benabbou, S. (2016). Key Determinants of Innovation in the Algerian SMEs. Topics in Middle Eastern \& North African Economies: Proceedings of the Middle East Economic Association, $18(1)$ 183-200.

http://www.redibw.de/db/ebsco.php/search.ebscohost.com/login.aspx\%3Fdirect\%3Dtrue\%26db\%3Dbuh\%26AN\%3D1178 $16623 \% 26$ site \%3Dehost-live

Abdu, M., \& Jibir, A. (2018). (2018). Determinants of firms innovation in Nigeria. Kasetsart Journal of Social Sciences., 39(3), 448-456.

Adebowale, B. A., Diyamett, B., Lema, R., \& Oyelaran-Oyeyinka, O. (2014). No Title. Innovation Research and Economic Development in Africa. African Journal of Science, Technology, Innovation and Development, 6(5), $\mathrm{V}-\mathrm{XI}$.

Bos, J. W., Kolari, J. W., \& van Lamoen, R. C. (2013). Competition and innovation: Evidence from financial services. Journal of Banking \& Finance, 37(5), 1590-1601., 37(5).

Božić, L., \& Rajh, E. (2016). The factors constraining innovation performance of smes in Croatia. Economic Research-Ekonomska Istrazivanja , 29(1), 314-324. https://doi.org/10.1080/1331677X.2016.1168040

Cisková, P., \& Durčeková, I. (2019). Determinants of firms' innovation activities in V4 countries. Statistika, 99(4), 369-382.

Gebreeyesus, M. (2014). Research Paper No . 2009 / 51 Innovation and Microenterprises Growth in Ethiopia Mulu Gebreeyesus *. May.

Havierniková, K., \& Kordoš, M. (2019). Factors Affecting Innovative Activities of SMEs in Slovak Regions. SHS Web of Conferences, 61, 01004. https://doi.org/10.1051/shsconf/20196101004

Kotey, B., \& Sorensen, A. (2014). Kotey, B., \& Sorensen, A. Australasian Journal of Regional Studies, The, 20(3), 405-429., 20(3), 405-429.

Kruger, R. O. (1991). The Small Business Development Center Program: From a small business growth stage and adult learning perspective (Doctoral dissertation, Portland State University).

Mancusi, M. L., \& Vezzulli, A. (2010). Mancusi, M. L., \& Vezzulli, A. R\&D, Innovation and Liquidity Constraints., 3-4.

Njiraini, P., Gachanja, P., \& Omolo, J. (2018). Factors influencing micro and small enterprise's decision to innovate in Kenya. Journal of Global Entrepreneurship Research, 8(1), 0-9. https://doi.org/10.1186/s40497018-0132-4

OECD. (2018). Chapter 7 . Measuring external factors influencing innovation in firms. In Oslo ManuaL (pp. 145$163)$.

Szczepanska-Woszczyna, K. (2014). Determinants of Innovation Activities in Small and Medium-Sized Enterprises in Poland. Journal of Advanced Research in Management, 5(2(10)), 65-73. https://www.proquest.com/scholarly-journals/determinants-innovation-activities-smallmedium/docview/1689988251/se-2?accountid=14570\%0Ahttps://primo49man.hosted.exlibrisgroup.com/openurl/MAN/MAN_UB_service_page?url_ver=Z39.882004\&rft val $\mathrm{fmt}=$ info:ofi/fmt

Talegeta, S. (2014). Innovation and barriers to innovation: small and medium enterprises in Addis Ababa. Journal of Small Business and Entrepreneurship Development, 2(1), 83-106.

Voeten, Jaap; Gizaw, B., \& Publication. (2018). Qualitative Study on Innovation in Manufacturing Small and Medium- Sized Enterprises ( SMEs ) in Ethiopia. Exploration of Policy and Research Issues.

Zajkowska, M. (2015). The Role Of Leadership In The Process Of Creating Innovation In The Organization On The Example Of Polish Companies 2. Characteristics of current innovation activity of Polish companies. IX, $129-142$.

Zastempowski, M., \& Przybylska, N. (2016). Cooperation in Creating Innovation in Polish Small and MediumSized Enterprises in the Light of Empirical Studies. Journal of Competitiveness, 8(2), 42-58. https://doi.org/10.7441/joc.2016.02.04

Zeleny, M. (2012). (2012). High technology and barriers to innovation: From globalization to relocalization. International Journal of Information Technology \& Decision Making, 11(02), 441-456. 